\title{
Effectivenes of group counseling with people-centered approach to improve student's social skills
}

\author{
Rini Larassati ${ }^{*}{ }^{1}$, Suwarjo ${ }^{2}$ \\ Universitas Negeri Yogyakarta \\ ${ }^{*}$ Corresponding author, $\equiv$ e-mail: larassatirini@gmail.com
}

\begin{abstract}
Humans are social beings who cannot live alone and always have relationships with others. Each individual is expected to relate well with other individuals in order to fulfill social needs. Fulfillment of good relationships with others requires skills of social skills. However, in reality there are still students who do not have good social skills. Therefore, the purpose of this study was to determine the effectiveness of group counseling with a person centered approach to students' social skills. The method used is quasi experimental research with non-equivalent control group design. The research was conducted in SMP Negeri 8 Yogyakarta with sample of 10 students of class VII. The instrument used in this study is the scale of social skills. Data analysis technique using wilcoxon test. The results showed that group counseling with a person centered approach was effective on the students' social skills.
\end{abstract}

Keywords: group counseling, person centered, social skills.

How to Cite: Larassati, R., \& Suwarjo. (2018). Effectivenes of group counseling with people-centered approach to improve student's social skills. Couns-Edu: International Journal of Counseling and Education, 3(4): pp. 133-139. DOI: https://doi.org/10.23916/0020180316440

(4) This is an open access article distributed under the Creative Commons Attribution License, which permits unrestricted use, distribution, and reproduction in any medium, provided the original work is properly cited. (C2018 by author.

\section{Introduction}

Humans are social beings who can not live alone and always have relationships with others. Learners are part of social beings who need others to help their survival, which is marked by the interaction with other individuals in the surrounding environment. This interaction will be more intensive and mature in adolescence. Based on the development phase, junior high school (junior high school) students enter the stage of teenage development. According to Papalia and Olds (in Jahja, 2011: 220) adolescence is a period of transition or transition from childhood to adulthood, which generally begins at the age of 12 or 13 years and ends in the late teens or early 20s . In addition Erickson (in Santrock, 2002: 43) reveals that in adolescence learners are expected to know his identity, knowing the advantages and weaknesses of the self, have ideals in life and began to take a role in activities in the environment. Therefore, when adolescents allow individuals to establish social relationships with other individuals in their environment.

Building relationships with others will make individuals experience more advanced growth, otherwise individuals who can not establish good relationships with others will experience obstacles in their growth. It shows that relationship with others is a significant and very important aspect for human life. Like the research conducted by Marriage (2005) which mentions that individuals lacking social skills, 
the individual is isolated from the association in his school and rejected by his peers (Painter, 2006: 13). The previous statement shows that establishing relationships with others is an important aspect of human life. In order for learners to establish a good relationship and acceptable to the environment, learners are expected to have a skill. Skills in question is a social skill. This is supported by the opinion of (Lee, 2015: 561) that social skills play a crucial role in enhancing collaboration and cooperation among individuals and in conflict resolution.

Corey (2013: 263) reveals that social skills are the ability to connect with others appropriately and effectively. Jarvela (2011: 137) defines social skills as the ability to be successful in relationships with others, both in school, workplace, family and community. In line with previous opinions (Frick, 2010: 150) defining social skills is a necessary skill to be successful in interacting with peers and adults. Social skills play an important role in one's life. Opinion (Matson, 2009: 2) social skills are special skills that need to be learned. Social skills are the ability of individuals to behave with other individuals to make individuals acceptable to their environment (Merrel, 2003: 313). Others argue that social skills are the ability to be able to do the deeds that will be accepted and avoid actions that will be rejected by the environment (Certledge \& Milburn, 1995: 151). Social skills have been conceptualized as skills that effectively understand social cues, precisely and accurately in interpreting interpersonal dynamics, and flexibly adjust one's behavior to respond to social demands (Sharon, 2012: 54).

However, in reality there are still learners who do not have social skills. of course this cooking will hinder the social life of learners in the school environment. Based on the results of media analysis of problem tracing (MLM), there are learners who have low social skills seen from students difficult to adapt to the environment as many as 64 students, less able to organize as many as 51 students, less able to interact as many as 37 students, and difficult to communicate as many as 34 learners. Of course it will hinder the lives of effective learners. Research conducted by Gottman (in Painter, 2006: 19) states that unskilled learners in social life will be socially rejected, and such rejection will occur throughout the ages and even into adulthood.

One of the most appropriate types of counseling and counseling services to assist students in improving social skills is group counseling services. Group counseling is one of the services in guidance and counseling with a group system. Group counseling is counseling using groups to help provide feedback and learning experiences and processes using group dynamics principles (Latipun 2008: 178). According to (Corey, 2012: 28) group counseling focused on issues of learning, career, and personal social. Group counseling activities are expected to be a means of self-development in order to learn to interact positively within the scope of small groups. Many approaches can be used in group counseling services, one of which is the person-centered approach. According to (Corey, 2013: 188) the group counseling approach can be applied in group processes. In a person-centered approach, counselors as group facilitators try to get the group to congruence, unconditional acceptance, and empathy. When group facilitators demonstrate a sense of trust to group members, accepting unconditionally, as well as counselors and group members can empathize about what individuals convey in groups can then develop attitudes and behaviors that enable members to interact with each other. Thus, group counseling services with a person-centered approach that will be provided to students continuously are expected to affect the social skills of learners.

\section{Method}

The research design in this study used quasi experimental (Creswell, 2010; Sugiyono, 2008). The design used is Non-equivalent Control Group Design. In this design the experimental group and the control group are equally given pre-test and post-test. However, only the experimental group was treated. The population in this study are students of class VII SMP Negeri 8 Yogyakarta, amounting to 278 students. Sampling technique in this research use purposive sampling technique. According to (Johnson \& Christensen, 2014: 364), purposive sampling is a non-random sampling technique in which the sample determines according to certain characteristics. Characteristics in question are learners who have social skills are in the low category. Based on the results of social skills scale, there are 10 students that will be divided into two groups, ie five students in the experimental group who will be given treatment using 
counseling service group of person-centered approach and five students in the control group are given treatment as done in school that is by technique discussion.

Data collection techniques used in this study by using the scale of social skills developed by researchers. In addition there are techniques of supporting data collection in the form of documentation methods, interviews. Stages or procedures in this study is the beginning stages, working stages and termination stages.

Data analysis technique used in this research is by using Wilcoxon Test that is increase of sign test, because in this research Pretest and Posttest test using SPSS (Statistical Package for Social Science) version 16. Based on wilcoxon test using SPSS 16 program, obtained level of significance, with qualification if sig. $<0,05$ then Ho is rejected and Ha accepted, meaning that there is improvement of social skill of learners after given treatment in form of group counseling with approach of person-centered.

\section{Results and Discussions}

The Based on the result of dissemination of social skill scale instrument to 278 students of class VII of SMP Negeri Yogyakarta, the percentage of social skills profile of learners is 143 students $(51,43 \%)$ are in high category, social skill in medium category as many as 125 students $(44.96 \%)$ and high social skills low category of 10 students (3.59). Based on previous explanation, it can be seen that the social skill of students of class VII of SMP Negeri 8 Yogyakarta is mostly in high category, but there are still students who are in medium and low category. The data is used as data pretest. Then 10 students who are in the low category were given treatment in the form of group counseling with the approach of person centered, after the treatments, experimental group and control group given post-test. The following table presents the pre-test and post-test of the experimental and control groups.

Table 1. Pretest and Posttest Results of Experimental Social Skills Group

\begin{tabular}{cccccc}
\hline No & Name (Initial) & $\begin{array}{c}\text { Score } \\
\text { Pretest }\end{array}$ & Category & Score & Category \\
& & & Posttest & \\
\hline $\mathbf{1 .}$ & BL & 93 & Low & 156 & High \\
$\mathbf{2 .}$ & JO & 92 & Low & 164 & High \\
$\mathbf{3 .}$ & HT & 95 & Low & 161 & High \\
$\mathbf{4 .}$ & AR & 94 & Low & 163 & High \\
$\mathbf{5 .}$ & YM & 95 & Low & 162 & High \\
\hline
\end{tabular}

Table 1 shows that the post-test value has an increase from the pre-test value. Overall the pre-test and post-test developments are presented in the following figure. 


\section{Improved Pre-Test Results And Post-Test Social Skills Experiment Group}

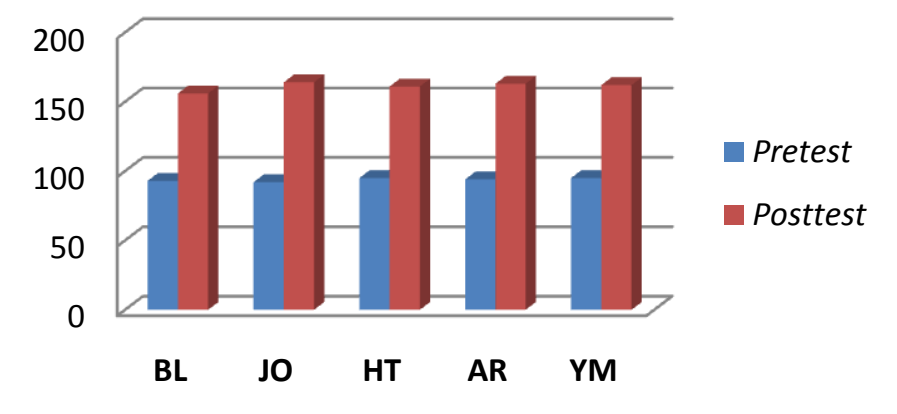

Figure 1. Graph of Pretest Development and Posttest of Social Skill of Experiment Group

Based on the results of pre-test and post-test, all learners who become samples experienced an increase in social skills. The observed changes that have shown behavior such as good relationships with peers, have good self-management, academic skills, compliance in social behavior, and assertive behavior. The results of the social skills of control groups are as follows:

Table 2. Pretest and Posttest Results of Social Skills of the Control Group

\begin{tabular}{cccccc}
\hline No & Name (Initial) & $\begin{array}{c}\text { Score } \\
\text { Pretest }\end{array}$ & Category & $\begin{array}{c}\text { Score } \\
\text { Posttest }\end{array}$ & Category \\
\hline $\mathbf{1 .}$ & RN & 93 & Low & 92 & Low \\
$\mathbf{2 .}$ & FT & 91 & Low & 91 & Low \\
$\mathbf{3 .}$ & PL & 96 & Low & 97 & Low \\
$\mathbf{4 .}$ & AN & 92 & Low & 90 & Low \\
$\mathbf{5 .}$ & VR & 98 & Low & 98 & Low \\
\hline
\end{tabular}

Table 2 shows no significant change between pre-test results and post-test results. Overall the pretest and post-test developments are presented in the following figure: 


\section{Improved Pre-Test Results And Post-Test Social Skills Control Group}

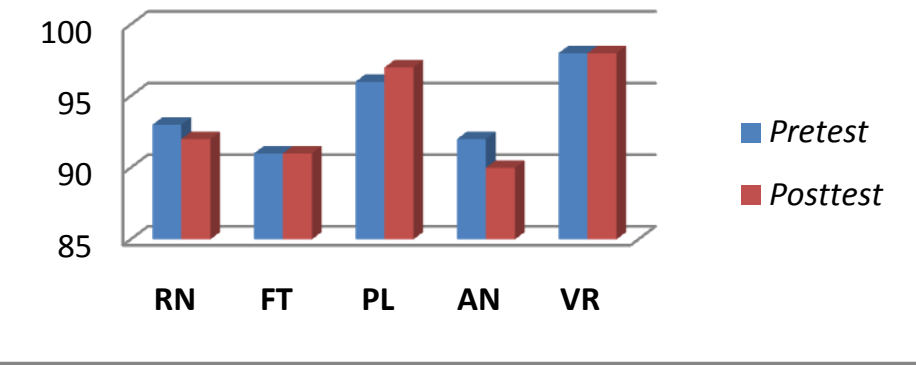

Figure 2 Graph of Pretest Development and Posttest of Social Skills Control Group

Based on the results of pre-test and post-test, all subjects in the control group did not experience significant improvement. The result of test of influence of group counseling with person-centered approach to individual social skill using wilcoxon test, while wilcoxon test of social skill in experimental group showed that there was difference of result before and after treatment (sig value $0,043<0,05$ ). In addition, there was an increase in the average pretest and posttest score of social skills in the experimental group of $67.4(93.80<161.20)$. While in the control group of wilcoxon test results showed that the sign value of 0.414 is greater than 0.05 , so it can be concluded that there is no significant difference before and after treatment. While based on the average value of pretest and posttest decreased by $0.4(94.00<93.60)$. Thus, it can be concluded that after being given treatment in the form of group counseling approach personcentered learners have increased social skills.

Group counseling is effective in helping individuals deal with social skills issues. Group counseling is a unique intervention system that differs significantly from procedures that can be described as guidelines and therapeutic processes commonly referred to as psychotherapy (Berg, 2006: 13). Group counseling is a type of group activity characterized by a dynamic interpersonal process in order to solve problems collectively in groups (Mapiare, 2010: 164). Group counseling is a counseling service between counselors and counselees in a group that utilizes group dynamics in the development and growth of group members (Jacobs, 2012: 13). In line with that opinion (Gibson \& Mitchell, 2011: 52) revealed that group counseling provides experiences to grow within the group.

The use of group centered counseling approaches can foster individual self-management skills such as being able to control emotions, follow rules and limitations, compromise with others, and be able to accept criticism well (Merrel 2003: 316). The previous opinion is similar to the opinion (Morgan, 2012: 6) which suggests that social skills are needed for school success because it can lead to behaviors such as pleasant behavior toward teachers, can express opinions and needs in a way that can control emotions, work together with peers and able to follow directions. Further (Lodder, 2016) discloses that learners who do not have good social skills will have difficulty interacting with others, limiting the quantity of social relationships, can not cope with life stressful events, and will affect the quality of low friendships.

The person-centered approach is one of the approaches of humanistic counseling. For counselors who use humanistic counseling, counselors will help counselees to improve self-understanding and be able to make decisions and as initiators of their own growth and development (Glading, 2015: 244). In line 
with (Sharf, 2012: 234) reveals that the individual is able to develop the ability to understand himself, able to change his own attitude and behavior.

In counseling groups of person-centered approaches believe that the individual has the power to be able to access the power within him, then in the counselor counseling process makes the individual realize that the individual has low social skills. Counseling groups of person-centered approaches train individuals to dare to speak or express their opinions and feelings, train individuals to mutual tolerance, train for mutual respect, train to respond to the opinions of others, train to interact and communicate. The group atmosphere created in long-term group counseling will affect the attitude and behavior of the individual so that the individual will follow whatever his friends do in groups. Knowledge of him will increase if the individual interacts with many friends who will improve social skills. someone with good social stature will show the behavior of providing help, being able to listen to others, communicate openly, be able to control emotions, be self, show concern for others, and be more confident (Santrock, 2011: 433).

Through a group atmosphere, individuals will gain knowledge about their weaknesses and strengths. The individual becomes aware that he or she has low social skills and it can disturb him in social relationships with others. The stronger the relationships created in the group the greater the group's influence on the individual. The influence appears like a tendency to speak, how to behave and behave. The process of impersonation done by individuals learned through the learning process in a group atmosphere that over time will create a picture of the individual's self how to behave and behave. Through group counseling, individuals can develop social aspects and abilities in social interaction with other group members. When in a group, individuals will be required the ability and social skills to be able to connect with others. Being willing to listen to others' opinions, expressing opinions, empathizing, cohesiveness is a positive thing for group members, so group process as one way to develop personality (Schmidt, 2003). A series of group counseling activities will be a learning process for each individual to learn new behaviors within the group to take positive values at each meeting that ultimately provide the expected improvement of social skills.

\section{Conclusions}

Based on the objectives, the results of the research discussion, it can be concluded that group counseling with the approach of person centered effectively on improving social skills of class VII students SMP Negeri 8 Yogyakarta. The result of the treatment is that students are able to establish good relationships with others, able to manage themselves, have academic skills, compliance and assertive behavior. Researchers realize there are still many shortcomings in this study. Therefore, it is hoped that the next researcher can research counseling group of person centered approach to improving social skills better.

\section{Acknowledgements}

In writing this article the author has been assisted by various parties. The parties who have helped and supported the completion of this article are Dr. Suwarjo, M.Si., my parents, and dear friends.

\section{References}

Berg, Robert C. (2006). Group counseling : concepts and procedures 4th Edition. New York. Routledge. Cartledge, M., \& Milburn, J. F. (1995). Teaching Social Skills to Children and Youth: Innovative Approaches. Boston: Allyn And Bacon.

Corey, Gerald. (2013). Theory and Practice of Counseling and Psychotherapy, 8th edition. USA: Brooks/cole, cengange learning.

Corey, Gerald. (2013). Theory and Practice of Counseling and Psychotherapy, 9th edition. USA: Brooks/cole, cengange learning.

Creswell, J. W. (2010). Research design pendekatan kualitatif, kuantitatif, dan mixed. Yogyakarta: Pustaka Pelajar. 
Frick, P.J., Kamphaus, R.W \& Barry, C.T. (2010). Clinical Assessmentof Child and Adolescent Personality and Behavior (Third Edition). New York: Springer Science Business Media.

Gibson, R.L dan Mitchell, M.H. (2011). Bimbingan dan Konseling (Edisi Tujuh). Yogyakarta: Pustaka Pelajar.

Gladding T. Samuel. (2015). Konseling Profesi Yang Menyeluruh. Jakarta: Indeks.

Jacobs, Ed E, et al., (2012). Group Counseling: Strategies and Skills, 7th Edition. USA: Brooks Cole.

Jahja, Yudrik. (2011). Psikologi Perkembangan. Jakarta: Kencana.

Jarvela, S. (2011). Social And Emotional Aspects Of Learning. Oxford. Elsevier Ltd.

Jhonson, B.R., \& Cristensen, L. (2014). Educational Research: Quantitative, Qualitative, and Mixed Approaches 5th Edition. United States of America: SAGE Publications, Inc

Latipun. (2008). Psikologi Konseling (Edisi Ketiga). Malang: Universitas Muhammadiyah Malang Press.

Lee, Dabae \& Huh, Y. (2015). Collaboration, Intragroup Conflict, And Social Skills In Project-Based Learning. Journal Counseling. 43:561-590 DOI 10.1007/s11251-015-9348-7.

Lodder, G.M.A.,Goossens, L., Scholte, R.H.J., Engels, R.C.M.E \&Verhagen. M. (2016).Adolescent Loneliness and Social Skills: Agreement and Discrepancies Between Self-, Meta-, and PeerEvaluations. Empirical Research. 45,2406-2416. http://doi10.1007/s10964-016-0461-y.

Mappiare, Andi. (2010). Pengantar Konseling dan Psikoterapi. Jakarta: PT. Raja Grafindo Persada.

Matson, J. L. (2009). Social Behavior and Skill in Children. New York: Baton Rouge.

Merrell, Kenneth W. (2003). Behavioral Social. And Emotional Assessment Of Children And Adolescents. New Jersey: Lawrence Erlbaum Associates, Inc., Publishers.

Morgan, J.J. (2012). Teaching Online Social Skills To Students With Emotional And Behavioral Disorders. (Doctor of Philosophy in Special Education, 2012). Department of Educational and Clinical Studies.

Painter, Kim Kiker. (2006). Social Skills Groups for Children and Adolescentswith Asperger's Syndrome: A Step-by-Step Program. London: Jessica Kingsley Publishers.

Santrock, J.W. (2002). Adolescence. (Tenth Edition). New York: The McGraw Hill Companies.

Santrock, J.W. (2011).Child Development Thirteenth Edition. New York:McGraw-Hil.

Sharf, S.D. (2012). Theories of psychotherapy and counseling. 5th Edition. USA: Brooks/Cole.

Sharon Y. Wu, K12 Inc. Daniel B. Turban. (2012). Social Skill In Workplace Mentoring Relationships. Journal of Organizational Culture, Communications and Conflict, Volume 16, Number 2, 2012University of Missouri Yu Ha Cheung, Hong Kong Baptist University.

Schmidt, J.J. (2003). Counseling in School, essential services and comprehensive program 4th Edition. USA: Pearson Education, Inc. 